\title{
POLLUTION OF NITRATES - CONTAMINANT TRANSPORT IN HETEROGENEOUS POROUS MEDIA: A CASE STUDY OF THE COASTAL AQUIFER OF CORINTH, GREECE
}

\author{
PSARROPOULOU E.T. \\ KARATZAS G.P.*
}

Received: 13/09/2013

Accepted:10/10/2013

\author{
School of Environmental Engineering \\ Technical University of Crete \\ Polytechneioupolis, Chania 73100, Greece
}

*to whom all correspondence should be addressed:

e-mail: karatzas@mred.tuc.gr

\section{ABSTRACT}

The coastal plain of Corinth, known also as Vocha plain, is one of the fast-growing rural areas due to its relatively short distance from Athens. In conjunction with the fast development, water use has also increased. On a large part of the Plain area, irrigated agriculture is practiced and fertilizers are applied. The groundwater is extracted by wells (boreholes) drilled in the alluvium of Vocha Plain to meet municipal, agricultural and other water requirements. Groundwater contamination by nitrates is a problem related mainly to the spreading of organic and chemical fertilizers by farmers and, to some extent, to effluents from domestic sewage systems. Groundwater pollution in the alluvium aquifer of the Vocha Plain was investigated during a field study from July 2000 to July 2001 at eight

(8) sampling periods. In this paper, the characteristics, distribution and variation of the $\mathrm{NO}_{3}^{-}$pollution are presented using a transport model.

KEYWORDS: Nitrate pollution; Groundwater model; Fate and Transport Model; Heterogeneous porous media; Corinth's coastal aquifer.

\section{INTRODUCTION}

Non-point-source pollution by agrochemicals is considered to be a major threat to the planet's groundwater resources. The main non-point-source pollutants are fertilizers, pesticides and salts contained in irrigation water. They are the main contaminants in the water that drains out of the root zone of crops from excess irrigation or rainfall and ends into groundwater (Bouwer, 2000). The threat to groundwater resources from non-point-source pollution is expected to increase in the future as irrigated agriculture and the use of agrochemicals will intensify to meet the demands for increased production. According to Hallberg (1989), the application of nitrogen-based fertilizers on irrigated crops is the most extensive human source of $\mathrm{NO}_{3}^{-}$in groundwater systems, while the amount of nitrate leached to the aquifer from agricultural lands is strongly influenced by factors inherent in nature, such as soil type and climatic conditions.

The coastal plain of Corinth, known also as Vocha Plain, is one of the fast-growing rural areas due to its proximity to Athens (Fig. 1). Its population has increased by 36\% from 1971 to 2001 and, in conjunction with the fast development, water use has also increased. The coastal aquifer is an important source of water and is utilized extensively to satisfy agricultural, domestic, and industrial water demands. Due to over-abstraction, excessive fertilization and untreated or poorly treated wastewater disposal, Corinth's Coastal Aquifer is experiencing both quantity and quality problems (Psarropoulou and Karatzas, 2001).

The increasing concern about the protection of water quality and the scarcity of available data has led managers to encourage the development of simulation tools able to mimic the water and nitrogen behavior and transport at a regional scale. In this work, a model has been developed to simulate the nitrate transport in the body of the aquifer system at a regional scale based on a previously established fully transient groundwater flow model (Psarropoulou and Karatzas, 2011). To evaluate 
the risk of aquifer pollution from non-point sources, it is necessary to describe the groundwater flow patterns in the area of interest; however, these are heavily influenced by the heterogeneity of the hydraulic properties of the surrounding geological formations and the intensive pumping. The transport model is used to assess the impact of diffuse nitrogen pollution on groundwater resources.

Nitrate $\left(\mathrm{NO}_{3}^{-}\right)$is the main form of $\mathrm{N}$ which occurs in groundwater. Nitrate is becoming increasingly widespread because it is soluble in water and is a highly mobile anion in the natural environment. Solubility constraints do not limit concentrations of nitrate in the range reported for groundwater. In strongly oxidizing groundwater, nitrate occurs as the stable form of dissolved nitrogen, which moves with no transformation and little or no retardation (Freeze and Cherry, 1979).

Sources of groundwater contamination by nitrate can be classified into point and non-point sources. Non-point sources of nitrogen include fertilizers, manure application, leguminous crops, irrigation return-flows, dissolved nitrogen in precipitation, and dry deposition. Nitrogenous fertilizers applied to cropped fields reach the groundwater as nitrates dissolved in the water percolating out of the crop root zone from excess rainfall or irrigation. The concentration of nitrate in the percolated water depends on field water and nitrogen balances. Its concentration in groundwater depends on recharge from other sources as well (e.g., seepage), groundwater flow and solute transport within the aquifer. In our study area, farmers do not usually keep records of irrigation water or fertilizer quantities applied to a crop, and these amounts vary considerably both spatially and temporally. An overriding problem is that there are about as many management practices as there are growers and it is hard to obtain an average estimate of the amount of irrigation or fertilizer applied.

Point sources, such as septic systems and cesspits, can also be major sources of nitrate pollution

(Babiker et al., 2004; Almasri and Kaluarachchi, 2005). Potential sources of $\mathrm{NO}_{3}^{-}$, particularly in the study area, include mainly agrochemicals, $\mathrm{N}$-fertilizers and effluents from septic systems (Daskalaki et al., 1998). Due to the fact that there are not any records either for the fertilizers applied or for the effluent from the septic systems, we need an indirect approach in order to assess the nitrogen loading to our groundwater system.

The basic idea of this paper is to use an already calibrated transient groundwater flow model for the development of a transport model and through that to assess the strengths and the weaknesses of this method. The final goal of the transport model is to assess the impact of diffuse nitrogen pollution on groundwater resources.

\section{THE STUDY AREA - GEOLOGICAL SETTING}

The plain is covered by Pliocene marine and lacustrine strata overlain by successions of Pleistocene fluvial and lacustrine sediments. The strata are covered by recent unconsolidated material consisting of sand, pebbles, breccias and fine clay to silty sand deposits (Fig. 1). Lateral continuity of the layers is often disrupted either by faults (Fig. 2) or by recent and older fluvio-torrential deposits originating from the streams that flow across the study area.

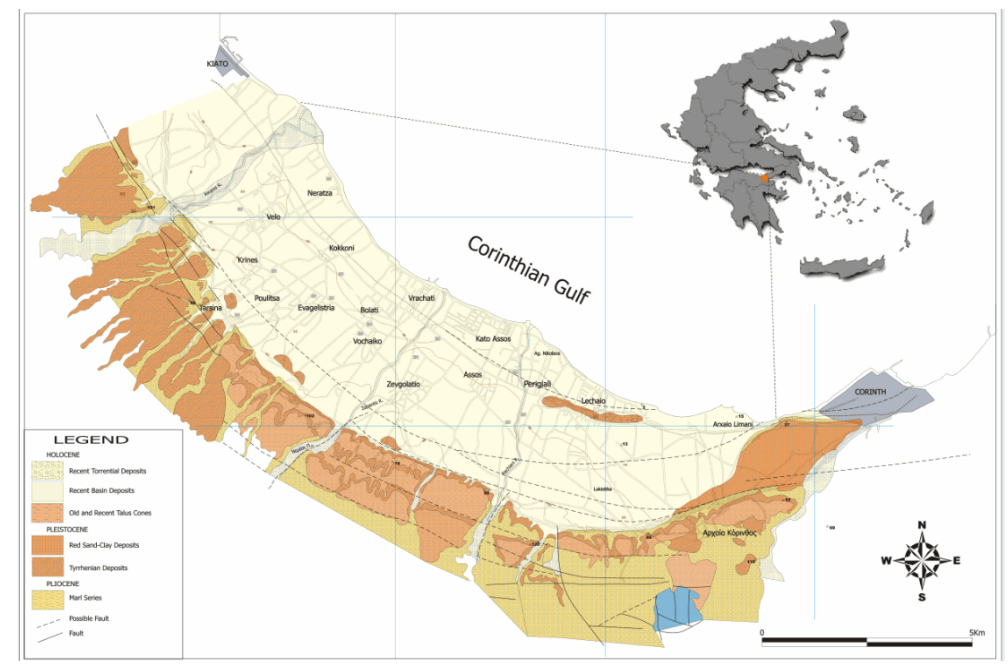

Figure 1. Geological Map of the study area (Inst. of Geology and Mineral Exploration, Greece) 
A WNW-ESE trending fault zone along the national highway delineates the Southern edge of the plain, which is bounded by the Corinthian Gulf to the North. South of the national highway, terraces of marine origin crop out. Marine terraces consist mainly of highly consolidated breccioconglomerates, sand, small gravel and marl intercalations. The Pliocene marl series, which is considered as aquitard, occupies most of the hilly region further south of the studied area and forms the "bedrock" of the studied aquifer system.

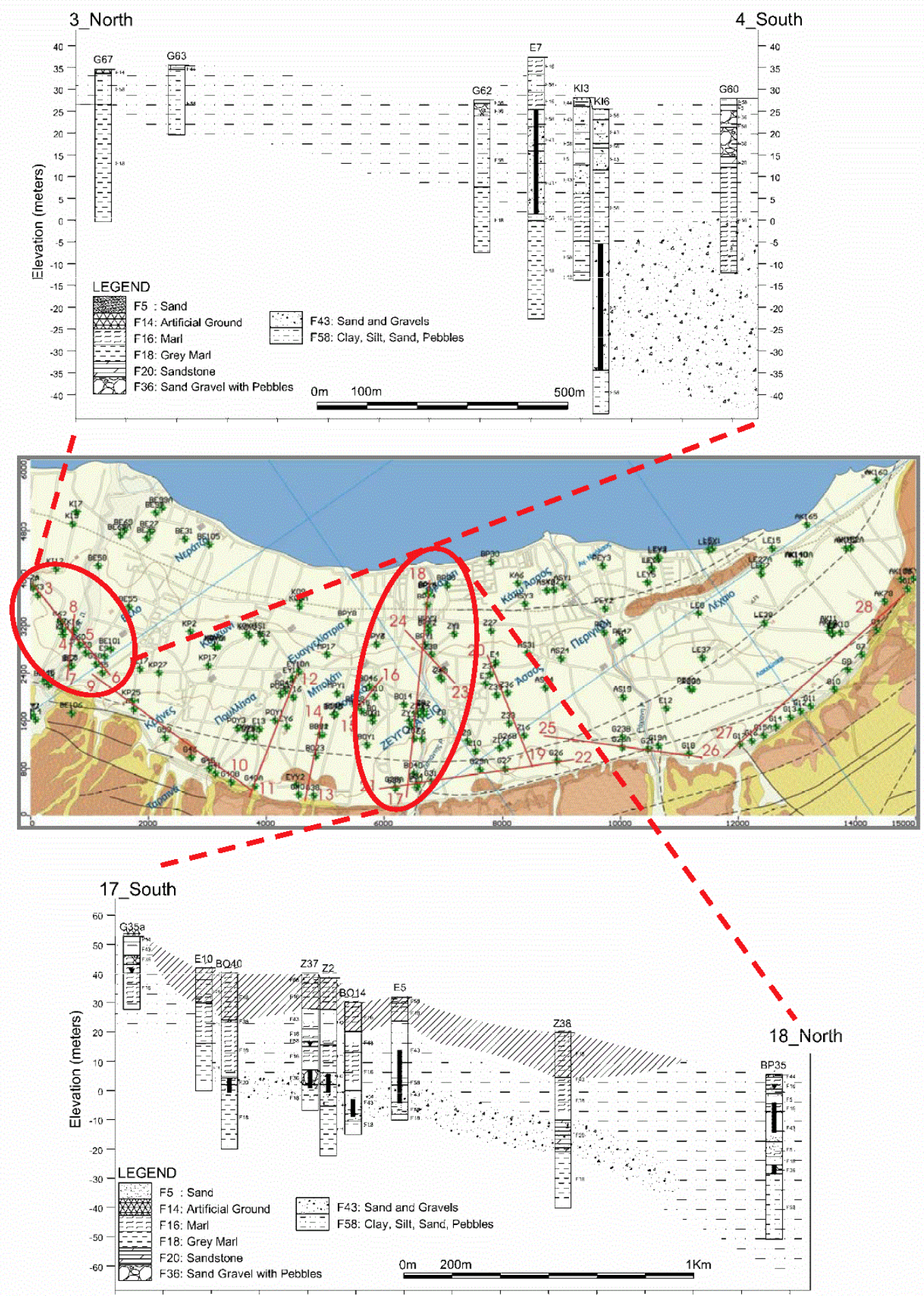

Figure 2. Hydro-Geological Cross Sections A3-B4 and C17-D18

The thickness of the alluvium is about $100 \mathrm{~m}$ in the central part of the plain and $20-40 \mathrm{~m}$ near its boundary. After careful examination and comparison of lithological sections of 108 boreholes drilled 
in the region, a series of hydro-geological cross sections were constructed, and two of them are presented in this paper (Fig. 2). The thickness of the plain deposits ranges from 20 to $70 \mathrm{~m}$, whereas along Asopos River there are indications that the layer width exceeds $100 \mathrm{~m}$. Due to the active tectonic environment and their origin, plain deposits are characterized by a high degree of heterogeneity and anisotropy both in the horizontal and the vertical scale.

Under natural conditions, the system is replenished by lateral flow coming from the marine terraces in the South boundaries. It may also gain some recharge by local infiltration of the precipitation, but more important for the aerial replenishment of the aquifer is the applied irrigation with water from the Asopos River utilizing an extended irrigation system covering the plain. Groundwater flows predictably under dynamic equilibrium through the plain area from South to North, where the system discharges its water through seepage into the Corinthian Gulf. Seasonal changes in water table elevation range from 1-3 m due to complex geology and different abstraction rates between dry and wet seasons.

Numerous wells (mostly illegal) that supply water for municipal, industrial and irrigation purposes have been drilled in the alluvium. During the first phase of the study, 650 wells were identified and mapped in the plain area while hydrogeological data were collected from selected wells. In general, the depth of the wells ranges from 25 to $100 \mathrm{~m}$ while groundwater levels measured in the wells during the field work were about $2-20 \mathrm{~m}$ from ground surface. All heads in the flow model are computed from mean sea level.

\section{MATERIALS \& METHODS}

The methodology followed is based on utilizing an already calibrated Transient Groundwater Model with Spatio-Temporally variable fluxes to build a simple transport model based on limited groundwater sampling.

\subsection{Groundwater Sampling and Analysis}

This study included eight samplings in selected wells during the period from July 2000 to July 2001. The sampling stations are shown in Figures 3 and 4. Sampling wells were selected to represent the entire study area and 265 groundwater samples were taken from these wells. Groundwater samples were collected in accordance with field techniques, as described in Panno et al. (1996). All samples were stored in polyethylene bottles and transported in ice-filled coolers to the laboratory. Samples were kept refrigerated at approximately $4{ }^{\circ} \mathrm{C}$ until analyses were completed in approximately two days. Nitrate, Nitrite and ammonia concentrations were measured by standard spectrometry methods using a Shimadzu spectrophotometer.

Chemical analysis of the groundwater samples produced the statistical values shown in Table 2 . The survey of nitrate concentrations in the coastal groundwater showed that more than half of the samples from 46 wells exceeded the maximum allowable limits according to directive 98/83/EC. These results show that in $50-70 \%$ of the samples, nitrate concentration surpassed that of $50 \mathrm{mg} \mathrm{I}^{-1}$

as $\mathrm{NO}_{3}^{-}$which is the highest nitrate concentration permitted in drinking water by the World Health Organization (Safe Drinking Water Comm., 1980 and the EEC standards).

Concentrations of Nitrates are presented by iso-concentration contour maps in Fig. 3 and Fig. 4 while statistical data of the chemical analysis are presented in Table 1 and Table 2.

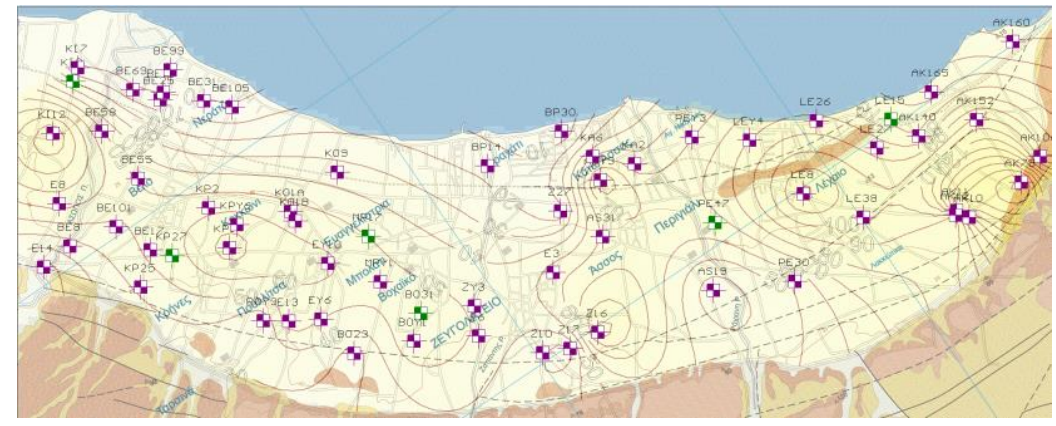

Figure 3. Sampling points. Distribution of Nitrate concentrations in groundwater in October 2000 - low water period (contour interval $10 \mathrm{mg} \mathrm{l}^{-1}$ ) 


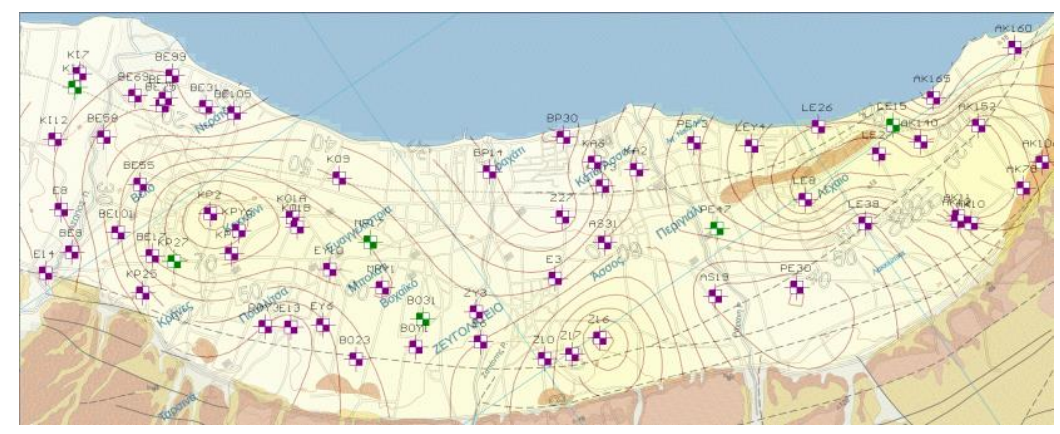

Figure 4. Sampling points. Distribution of Nitrate concentrations in groundwater in March 2001 - high water period (contour interval $10 \mathrm{mg} \mathrm{l}^{-1}$ )

Table 1. Analyses of water samples from wells in Vocha Plain - Concentrations of $\mathrm{NO}_{3}^{-}\left(\mathrm{mg} \mathrm{l}^{-1}\right)$

\begin{tabular}{cccc}
\hline Wells & \multicolumn{3}{c}{$\mathrm{NO}_{3}^{-}\left(\mathrm{mg} \mathrm{I}^{-1}\right)$} \\
\hline AK10 & min & mean & $\max$ \\
\hline AK106 & 16.1 & 84.59 & 95.59 \\
\hline AK11 & 92.64 & 131.67 & 101.51 \\
\hline AK12 & 88.93 & 114.91 & 130.86 \\
\hline AK140 & 40.75 & 71.02 & 101.88 \\
\hline AK152 & 94.21 & 121.44 & 164.38 \\
\hline AK160 & 40.25 & 66.06 & 89.3 \\
\hline AK165 & 41.38 & 57.22 & 65.53 \\
\hline AK78 & 90.06 & 130.87 & 188.13 \\
\hline AS19 & 2.85 & 25.28 & 52.77 \\
\hline ASY3 & 33.77 & 33.77 & 33.77 \\
\hline BE105 & 0.75 & 1.24 & 1.57 \\
\hline BE17 & 51.89 & 57.95 & 65.0 \\
\hline BE27 & 11.25 & 13.71 & 16.35 \\
\hline BE55 & 47.55 & 52.14 & 60.13 \\
\hline BE58 & 22.64 & 26.19 & 36.48 \\
\hline BE69 & 1.76 & 9.84 & 16.92 \\
\hline BE8 & 0.63 & 2.46 & 4.28 \\
\hline BE99 & 1.89 & 13.93 & 22.64 \\
\hline BO & 59.75 & 61.93 & 65.41 \\
\hline BO23 & 25.22 & 37.56 & 47.17 \\
\hline BP14 & 14.72 & 23.33 & 39.87 \\
\hline & & &
\end{tabular}

\begin{tabular}{cccc}
\hline Wells & \multicolumn{3}{c}{$\mathrm{NO}_{3}^{-}\left(\mathrm{mg} \mathrm{I}^{-1}\right)$} \\
\hline & min & mean & $\max$ \\
\hline BP30 & 0.94 & 6.99 & 14.21 \\
\hline E13 & 19.37 & 54.46 & 70.82 \\
\hline E8 & 45.28 & 60.96 & 78.05 \\
\hline EY10 & 0.94 & 64.88 & 119.38 \\
\hline EY6 & 11.88 & 61.48 & 69.38 \\
\hline KA6 & 22.01 & 36.92 & 58.99 \\
\hline KO9 & 14.21 & 36.69 & 49.25 \\
\hline KP2 & 76.48 & 92.76 & 45.0 \\
\hline KP25 & 33.52 & 43.12 & 68.88 \\
\hline LE2 & 0.82 & 46.79 & 71.7 \\
\hline LE26 & 55.53 & 75.55 & 104 \\
\hline LE27 & 57.55 & 132.58 & 235.85 \\
\hline LE38 & 54.4 & 73.56 & 102.52 \\
\hline LE8 & 114.03 & 124.46 & 137.25 \\
\hline PE30 & 11.5 & 32.03 & 51.89 \\
\hline POY3 & 31.45 & 50.74 & 64.4 \\
\hline K01A & 18.11 & 40.74 & 52.0 \\
\hline KO1B & 9.26 & 37.86 & 53.63 \\
\hline Z16 & 98.55 & 114.79 & 126.0 \\
\hline Z17 & 0.63 & 38.19 & 87.11
\end{tabular}

Table 2. Statistical Values from chemical analysis $\left(\mathrm{NO}_{3}^{-}, \mathrm{NO}_{2}^{-}\right.$and $\left.\mathrm{NH}_{4}^{+}\right)$

\section{SAMPLING -OCTOBER 2000 (42 SAMPLES)}

\begin{tabular}{|c|c|c|c|}
\hline Anions & Max limit $\left(\mathrm{mg} \mathrm{l}^{-1}\right.$ ) according to directive 98/83/EC & $\begin{array}{c}\text { Number of samples } \\
\text { above limits }\end{array}$ & $\begin{array}{c}\text { Percentage \% of } \\
\text { samples above limit }\end{array}$ \\
\hline $\mathrm{NO}_{3}^{-}$ & 50 & 21 & $50 \%$ \\
\hline $\mathrm{NO}_{2}^{-}$ & 0.5 & 1 & $2.3 \%$ \\
\hline $\mathrm{NH}_{4}^{+}$ & 0.5 & 4 & $9.5 \%$ \\
\hline & Sum of 25 samples above limits & & $59.5 \%$ \\
\hline \multicolumn{4}{|c|}{ SAMPLING -MARCH 2001 (37 SAMPLES) } \\
\hline Anions & Max limit $\left(\mathrm{mg} \mathrm{l}^{-1}\right)$ according to directive 98/83/EC & $\begin{array}{c}\text { Number of samples } \\
\text { above limits }\end{array}$ & $\begin{array}{c}\text { Percentage \% of } \\
\text { samples above limit }\end{array}$ \\
\hline $\mathrm{NO}_{3}^{-}$ & 50 & 17 & $46 \%$ \\
\hline $\mathrm{NO}_{2}^{-}$ & 0.5 & 2 & $5.4 \%$ \\
\hline $\mathrm{NH}_{4}^{+}$ & 0.5 & 6 & $16.2 \%$ \\
\hline & Sum of 24 samples above limits & & $65 \%$ \\
\hline \multicolumn{4}{|c|}{ SAMPLING -JULY 2001 (36 SAMPLES) } \\
\hline Anions & Max limit $\left(\mathrm{mg} \mathrm{l}^{-1}\right)$ according to directive 98/83/EC & $\begin{array}{c}\text { Number of samples } \\
\text { above limits }\end{array}$ & $\begin{array}{c}\text { Percentage \% of } \\
\text { samples above limit }\end{array}$ \\
\hline $\mathrm{NO}_{3}^{-}$ & 50 & 25 & $69.5 \%$ \\
\hline $\mathrm{NO}_{2}^{-}$ & 0.5 & 1 & $3 \%$ \\
\hline $\mathrm{NH}_{4}^{+}$ & 0.5 & 3 & $8.5 \%$ \\
\hline
\end{tabular}


At the end of summer, usually the level of the water table is as low as it can be due to the use of groundwater for irrigation. In October 2000, the water level just started to rise while in March 2001 the water table was at its high level due to winter and early spring rainfalls. A close examination of the nitrate concentration contour maps (Figs. 3 and 4) reveals that when the water level is rising (March 2001) nitrate concentrations are also rising and are more disperse.

In both periods, the highest nitrate concentrations were observed in the Eastern parts of the plain area.

\subsection{Modeling of Groundwater Flow and Nitrate Transport \\ 3.2.1 The Numerical Code}

The next major step in this framework was the development of the nitrate fate and transport model. The partial differential equation that governs the three-dimensional transport of a single chemical constituent in groundwater, considering advection, dispersion, fluid sinks/sources, equilibriumcontrolled sorption, and first-order irreversible rate reactions is as follows (Zheng and Wang, 1998):

$$
\frac{\partial(\theta \mathrm{C})}{\partial \mathrm{t}}=\frac{\partial}{\partial \mathrm{x}_{\mathrm{i}}}\left(\theta \mathrm{D}_{\mathrm{ij}} \frac{\partial \mathrm{C}}{\partial \mathrm{x}_{\mathrm{j}}}\right)-\frac{\partial}{\partial \mathrm{x}_{\mathrm{i}}}\left(\theta \mathrm{v}_{\mathrm{i}} \mathrm{C}\right)+\mathrm{q}_{\mathrm{s}} \mathrm{C}_{\mathrm{s}}+\sum \mathrm{R}_{\mathrm{n}}
$$

where:

$\mathrm{C}$ is the dissolved concentration $\left[\mathrm{ML}^{-3}\right]$;

$\mathrm{t}$ is time [T];

$\theta$ is the porosity of the medium, dimensionless;

$D_{i j}$ is the hydrodynamic dispersion coefficient tensor $\left[\mathrm{L}^{2} \mathrm{~T}^{-1}\right]$;

$\mathrm{V}_{\mathrm{i}}$ is the pore water velocity $\left[\mathrm{LT}^{-1}\right]$;

$q_{s}$ is the volumetric flow rate per unit volume of aquifer which represents fluid sources and sinks $\left[\mathrm{T}^{-1}\right]$;

$\mathrm{C}_{\mathrm{s}}$ is the concentration of the fluid source or sink flux $\left[\mathrm{ML}^{-3}\right]$;

$\sum R_{n}$ is the chemical reaction term $\left[\mathrm{ML}^{-3} \mathrm{~T}^{-1}\right]$.

As can be concluded from Eq. (1), the nitrate fate and transport model requires the velocity of the groundwater flow. For the purposes of this paper, we used the velocity field from a previously established transient three-dimensional groundwater flow model for the particular aquifer system (Psarropoulou and Karatzas, 2011). This transient three-dimensional groundwater flow model was developed using Visual MODFLOW - version 4.2 (Waterloo Hydrogeologic Inc., 2006) as pre and post processor to calculate the resulting water table elevations according to the following equation (McDonald and Harbaugh, 1988):

$$
\frac{\partial}{\partial x}\left(\mathrm{~K}_{x x} \frac{\partial \mathrm{h}}{\partial \mathrm{x}}\right)+\frac{\partial}{\partial \mathrm{y}}\left(\mathrm{K}_{\mathrm{yy}} \frac{\partial \mathrm{h}}{\partial \mathrm{y}}\right)+\frac{\partial}{\partial \mathrm{z}}\left(\mathrm{K}_{\mathrm{zz}} \frac{\partial \mathrm{h}}{\partial \mathrm{z}}\right)+\mathrm{R}=S_{s} \frac{\partial h}{\partial t}
$$

where:

Kij are hydraulic conductivity components $\left[\mathrm{L} \mathrm{T}^{-1}\right]$;

$h$ is the hydraulic head [L];

$R$ is a volumetric flux per unit volume which represents sources and/or sinks of water $\left[\mathrm{L}^{3} \mathrm{~L}^{-3}\right]$

and Ss is the specific Storage of the porous material; while $t$ is time.

The solution of Eq. (2) provides a transient prediction of hydraulic head in a three-dimensional domain for an anisotropic hydraulic-conductivity field. Head differences between observed and calculated data were computed at each time step. The reactive mass transport model, MT3DMS (Zheng and Wang, 1998), was used as the simulation model linked to the saturated flow model MODFLOW (McDonald and Harbaugh, 1988). According to the above, the fate and transport of nitrate in groundwater was computed for the study area. 


\subsubsection{The Conceptual Model}

The transient three-dimensional (3-D) simulation model of the coastal aquifer is based on the assumptions and principles of the conceptual hydrogeological model. This led to the decision to model an area which covers around $60 \mathrm{~km}^{2}$ (Fig. 1) and lies in a zone under the influence of groundwater flow coming from the marine terraces at the hilly area in the South.

The geology of the Corinthos plain area as previously established is complex, especially in the center of the study area because of the strong lateral and vertical variations in sedimentary facies. This made a uniform and homogeneous one layer approximation hard to apply in the plain area. Consequently, for groundwater modelling purposes, the conceptual model was divided in four layers to represent the system according to average lithology and the zonation assumed for the hydraulic properties.

In Vocha plain, groundwater flow occurs under water table conditions in the upper units and under semi-artesian conditions in the remaining part of the system. The degree of confinement increases with depth due to increased stratification and the presence of numerous discontinuous clayey and marly beds of low permeability. Individually these zones and beds do not constitute distinct confining units, but their combined influence significantly impedes vertical movement of groundwater. In spite of the apparent heterogeneity, the aquifers and their subunits are interconnected to a greater or a lesser degree and together constitute a system that provides relatively continuous flow in the region.

\subsubsection{Model Parameters}

In the present study, it would be practically impossible to model groundwater flow at such a scale to take into account the effects of fine-scale sedimentary heterogeneity. In fact, this would require a precise knowledge of the sedimentary bodies that cannot be obtained from sparse data and also would be prohibitive by the required computing power. Therefore, the "fine" scale heterogeneity is usually 'upscaled' and the heterogeneous real medium is substituted at a larger scale with an equivalent, often anisotropic medium, whose parameters allow the reproduction of the average flow of the real heterogeneous sedimentary structure.

Following the definitions by Koltermann and Gorelick (1996) for the hydraulic properties, we applied a descriptive approach using a zonation with homogeneous hydrofacies, based on geological information. Zonation reduces the number of parameter values and makes the task of numerical modelling easier. It minimizes the number of independent parameters and thereby adds statistical reliability to the parameter estimates. In the context of the present study, six zones were identified according to information from the available lithology logs in the plain area. The hydraulic conductivity values were adjusted through model calibration in order to minimize the difference between observed and calibrated head values (Table 3).

Table 3. Calibrated Conductivity parameters for the identified hydrofacies

\begin{tabular}{llll}
\hline Zones & $\mathbf{K x}\left(\mathbf{m ~ s}^{-1}\right)$ & $\mathbf{K y ~}\left(\mathbf{m ~ s}^{-1}\right)$ & $\left.\mathbf{K z} \mathbf{( m ~ s} \mathbf{~ s}^{-1}\right)$ \\
\hline (1) Blue & $2.23 \times 10^{-4}$ & $2.23 \times 10^{-4}$ & $1.2 \times 10^{-3}$ \\
\hline (2) Dark Green & $2.15 \times 10^{-3}$ & $2.15 \times 10^{-3}$ & $9 \times 10^{-4}$ \\
\hline (3) Light Green & $2.87 \times 10^{-4}$ & $2.87 \times 10^{-4}$ & $5.6 \times 10^{-4}$ \\
\hline (4) Gray & $2.83 \times 10^{-3}$ & $2.83 \times 10^{-3}$ & $1.2 \times 10^{-3}$ \\
\hline (5) Olive & $1.06 \times 10^{-5}$ & $1.06 \times 10^{-5}$ & $1.2 \times 10^{-4}$ \\
\hline (6) Maroon & $2.69 \times 10^{-4}$ & $2.69 \times 10^{-4}$ & $2.65 \times 10^{-6}$
\end{tabular}

The applied hydrological analysis of the region formed the basis for determining model boundaries, the number of aquifer layers to be modelled and the location and extent of each aquifer layer. Based on data availability and hydrogeological conditions the four layer aquifer system was discretized using orthogonal grids of 200 rows and 200 columns for simulating initially groundwater flow, with cell dimensions of $75 \mathrm{~m}$ by $30 \mathrm{~m}$ while null properties were assigned to cells outside the model domain. This spatial discretization of the model has been found to be adequate in view of the available data and the computational time. 


\subsubsection{Model Boundary Conditions - Recharge}

According to the hydrogeological conceptual model the following hydrological boundary conditions were set:

a) No flow boundaries assigned at the edges of the model area

b) Production wells (different pumping rates were assigned to 650 wells mapped in the area)

c) Surface recharge: Spatially and time varied net recharge representing both precipitation and irrigation. The values for areal recharge which are assigned are higher in order to calibrate the groundwater recharge, since the groundwater model can not differentiate the inputs from imported precipitation and irrigation.

d) General Head Boundary Condition: for representation of the lateral recharge of the aquifer from the South (Marine terraces)

The function of the general-head boundary package (GHB) is mathematically similar to that of the river, drain, and evapotranspiration packages. Flow into or out of a cell from an external source is provided in proportion to the difference between the head in the cell and the reference head assigned to the external source. The application of this boundary condition is intended to be general, as indicated by its name. The purpose of using this boundary condition is to avoid unnecessarily extending the model domain outward to meet the element influencing the head in the model (which is Marine terraces in our case). As a result, the general-head boundary condition was assigned along the outside edges of the model domain in the South.

Estimating the rate of aquifer replenishment $(Q)$ is probably the most difficult of all tasks in the evaluation of groundwater resources. While establishing the three dimensional transient groundwater flow model, we developed to a methodology for an indirect way to estimate the aquifer replenishment according to groundwater level fluctuations.

As climate variability increases, it is becoming increasingly critical to find predictable patterns that can still be identified despite overall uncertainty. In most cases, water level data appear to have a cyclic structure. This has been explored in several studies that suggest that cycles with different frequencies may exist in hydrologic as well as in climatic data (Currie, 1974; 1981; 1984; 1987; Currie and O'Brien, 1988; 1990; Labitzke et al., 1990; Burroughs, 2003; Ramachandra Rao and Hamed, 2003). These cycles may represent the influence of a number of natural phenomena such as the sunspot cycle with a period of about 11 years, the sun's magnetic (Hale) cycle with a period of 22 years, the Luni-Solar cycle with a period of about 18.6 years, El-Ninio-Southern Oscillations (ENSO) with periods of 2-3 and 4-6 years and other. Periods of 2-3 years are also known as the Quasi-Biennial Oscillations (QBO). (Ramachandra Rao and Hamed, 2003).

In general, time series containing a periodic sinusoidal component with a known wavelength can be modelled using harmonic equations. In water level data from Vocha plain aquifer, three main components of time series were recognized: an annual periodicity, an interdecadal periodicity and a long-term trend. In order to simulate the sum of the two observed physical periodicities (an annual and a long term periodicity) to water table fluctuation data, the sum of two harmonic equations was implemented and the resulting equation $f(t)$ was :

$$
f(t)=A_{0}+A_{1} \cos \left(\frac{2 \pi}{T_{1}} t+\phi_{1}\right)+B_{1} \sin \left(\frac{2 \pi}{T_{1}} t+\phi_{1}\right)+A_{2} \cos \left(\frac{2 \pi}{T_{2}} t+\phi_{2}\right)+B_{2} \sin \left(\frac{2 \pi}{T_{2}} t+\phi_{2}\right)+a t
$$

where

- $\quad f$ is the periodic sinusoidal component of water level for well AK10.

- $A_{1}, B_{1}, A_{2}$ and $B_{2}$ : amplitude is the peak deviation of the function from its center position

- $\mathrm{T}_{1}, \mathrm{~T}_{2}$ : the observed periodicities

- $\varphi_{1}, \varphi_{2}$ : the phase which specifies where in each cycle the oscillation begins at $t=0$.

- a constant term $A_{0}=\bar{x}$; where $\bar{x}$ is the average value of water table measurements in well $A K 10$

- the fitted trendline term; Fitted trend=at where $\alpha$ is the slope of the fitted trend line

The observed trend of water level which decreases with time can be attributed mainly to human induced factors, such as (1) the increased water abstractions (continuous population growth, intensive agriculture), (2) land use change due to rapid urbanization over the years, and last but not least (3) climate change. 
The sinusoidal model from the $f(t)$ equation, resulted in a complete time series of data, simulating water table observations at well AK10, considering the time period February 1998 - March 2007 as the calibration period and the period March 2007- January 2018 as the forecasting period (Fig. 5). The previous procedure was applied also to well (BE17) situated near the boundaries and the simulated water level series were used again as input for head depended flux boundary in the perspective area.

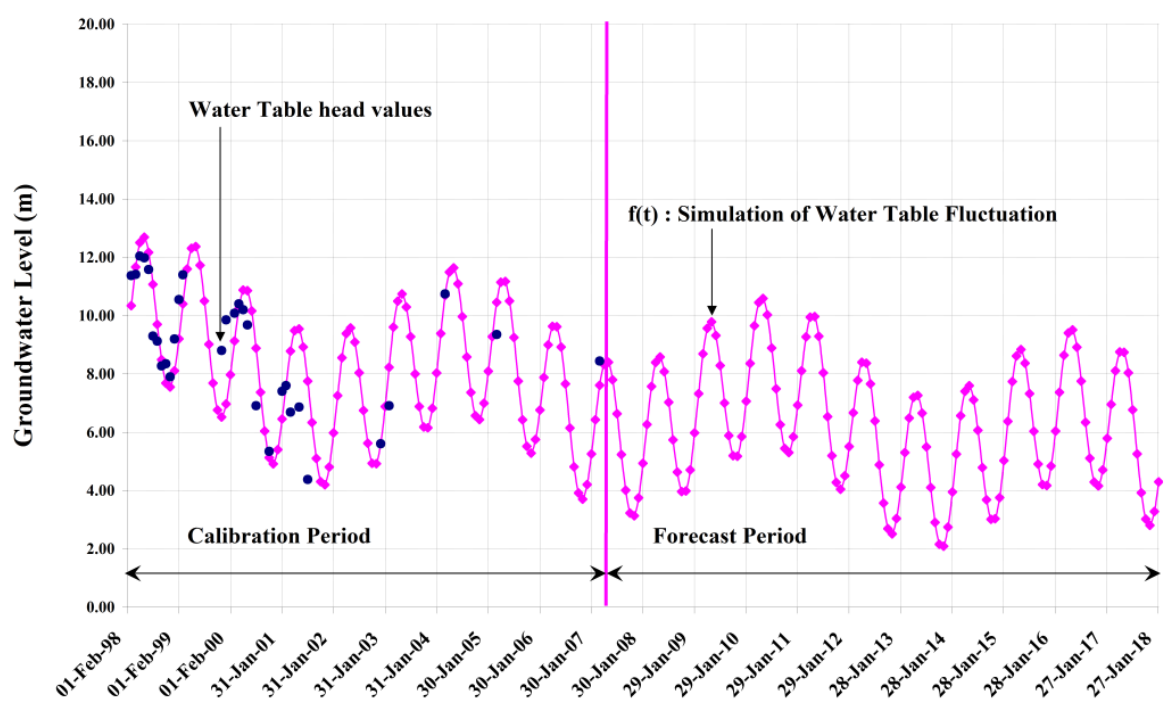

Figure 5. Observed (blue dots), calculated and forecasted groundwater levels for AK10.

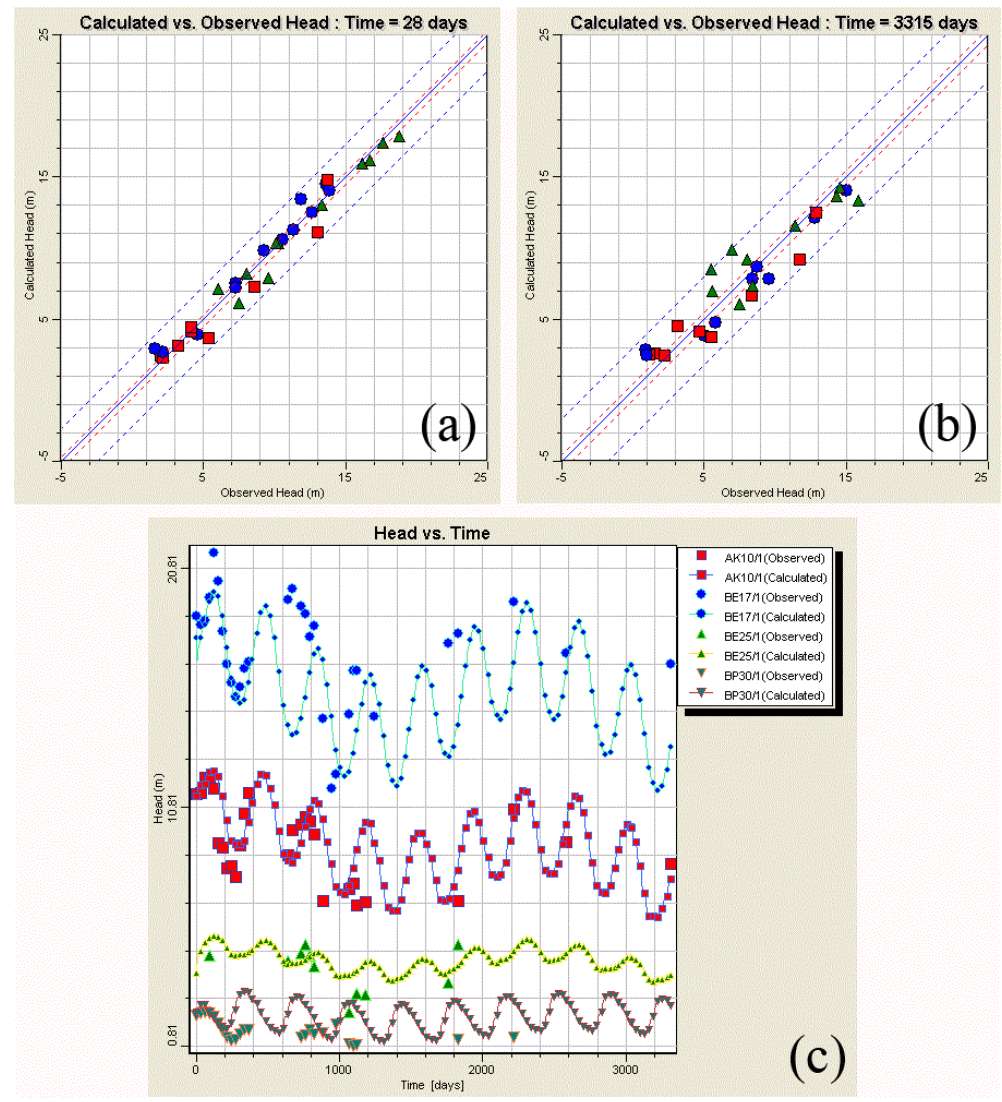

Figure 6. Calibration results: (a) observed versus computed head at observation wells in the start of the simulation (b) observed versus computed head at observation wells after running the model for almost ten years and (c) time series of groundwater head at selected four wells representing different areas of the model 
The groundwater model run with the specified boundary conditions as described earlier, initial conditions, recharge rates at each node and the specified pumping rates at all internal nodes for almost 10 years. The results of groundwater flow modelling are presented in Fig. 7 while Fig. 6 presents the calibration results. Observed versus computed heads at the observation wells in 1998 (2/1998 - start of the simulation) and 2007 are shown in Fig. 6a, b respectively. Fig. 6c presents a time series of groundwater heads at four widely separated observation wells. The calibration results show that the maximum head error is smaller than 2 meters which is reasonable for the size and the geological setting of the area. The model presented in this study was calibrated so that the differences between the observed and calculated heads were consistent with the uncertainties of the observed heads. Attempting to decrease the head differences further would have required additional changes to the transmissivity field. These changes may be physically meaningless and might result in the over calibration of the model rendering it ineffective for prediction purposes.

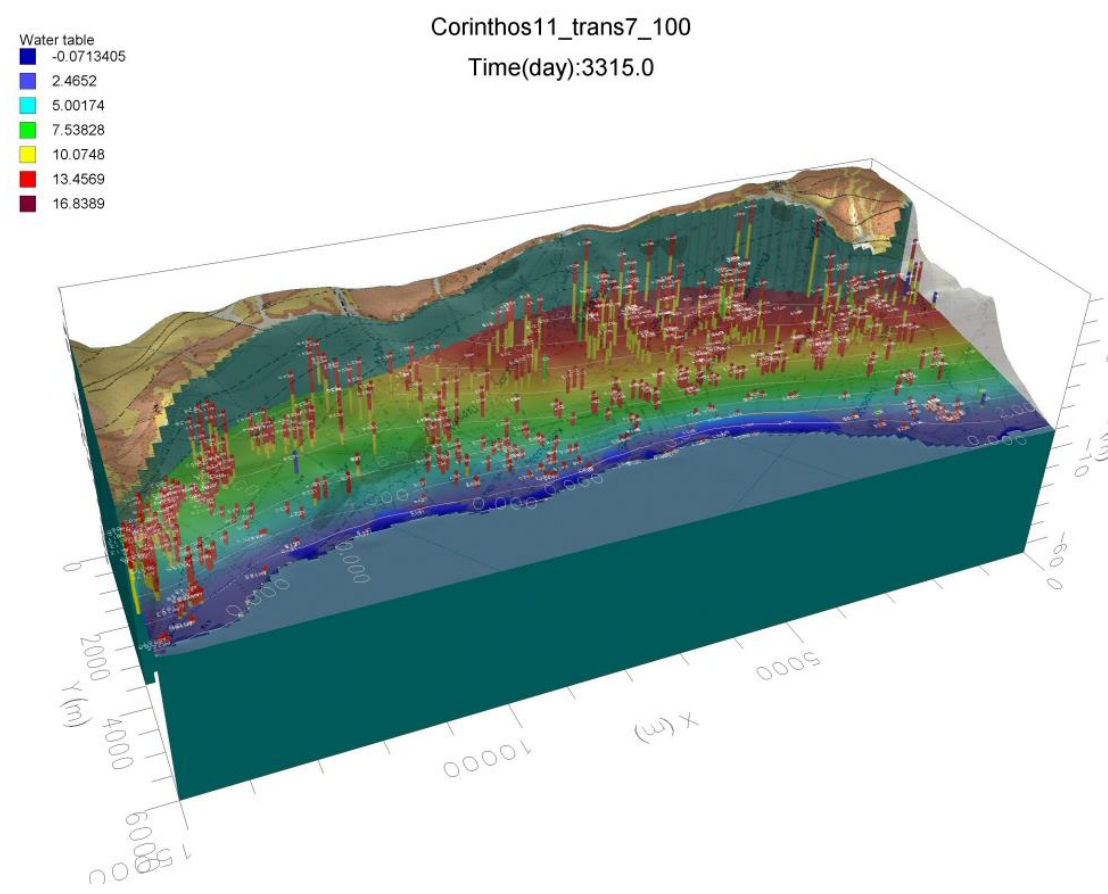

Figure 7. Results of the groundwater modeling after running the simulation for almost 10 years.

Red pins represent the production wells

\subsubsection{The Transport Model}

According to Eq. (1) there are four major processes that control the contaminant transport in groundwater: advection, hydrodynamic dispersion, soil adsorption, and geochemical reaction. Nonconservative contaminants are those that undergo attenuation through adsorption or geochemical reactions along the travel path, in addition to advection and dispersion. The transport of a conservative contaminant, such as Nitrate, is only affected by advection and dispersion. In other words, groundwater flow is the only force that determines the transport of a conservative contaminant, whereas the transport of a nonconservative contaminant is also controlled by processes that may change its mass in the groundwater aquifer. Nitrate is a highly mobile species with little sorption on the solid matrix and it is generally characterized as a conservative contaminant. Hence, sorption is neglected and the retardation coefficient is assumed to be one (Shamrukh et al., 2001).

On the basis of the flow model, the transport model was constructed, using $\mathrm{NO}_{3}^{-}$as a conservative contaminant. Initial conditions represent nitrate concentration at the beginning of simulation. Sinks and sources are considered as boundary conditions. They are classified as distributed or as points. So, pollutant recharge was represented mainly by concentration recharge boundaries in the Eastern 
part of the model. Nitrate leaching to groundwater from the soil was taken in the units of mass per liter $\left(\mathrm{mg} \mathrm{l}^{-1}\right)$ over model cells. Dispersivity values for $\mathrm{NO}_{3}^{-}$were selected from bibliographical data around $30 \mathrm{~m}$.

Since the current land use practices have been occurring in the study area for a long time except for small changes, nitrogen buildup in the soil and the transport of nitrate in the aquifer are expected to be in a quasi-steady state. That is, the annual mean value of nitrate concentration at a given location may be in a steady-state and the transient variation of nitrate concentration over a year at a given location may be approximately repeated every year. Therefore, the model at a specific location produces twelve dissimilar monthly nitrate concentration values every year and after reaching the quasi-steady state it repeats them on yearly basis.

The nitrate concentration data used in the calibration of MT3D model were obtained mainly from field sampling, as previously discussed, for the period June 2000 - June 2001. All available data were assembled into a single composite database which was assessed to determine its suitability for calibration. The analysis of the database showed that the nitrate concentrations of October 2000 are the best in terms of the spatial and temporal distribution. A surfer file of well spatial locations and corresponding data was developed and used as initial conditions.

\section{RESULTS AND DISCUSSION}

In this paper, we examined the ability of a calibrated three dimensional fully transient groundwater flow model to simulate the flux of a conservative contaminant like Nitrates.

Water in a high percentage of wells (about 50\%) during the period from October 2000 - July 2001 is characterized improper for human consumption because of the high nitrate content (samples with concentrations above $50 \mathrm{mg} \mathrm{l}^{-1}$ which is the upper limit in drinking water standards). This result shows that there is a significant problem of nitrate pollution in the study area. The nitrite and ammonia concentrations were also increased especially to specific wells probably due to local practices (artificial recharge with low quality water).

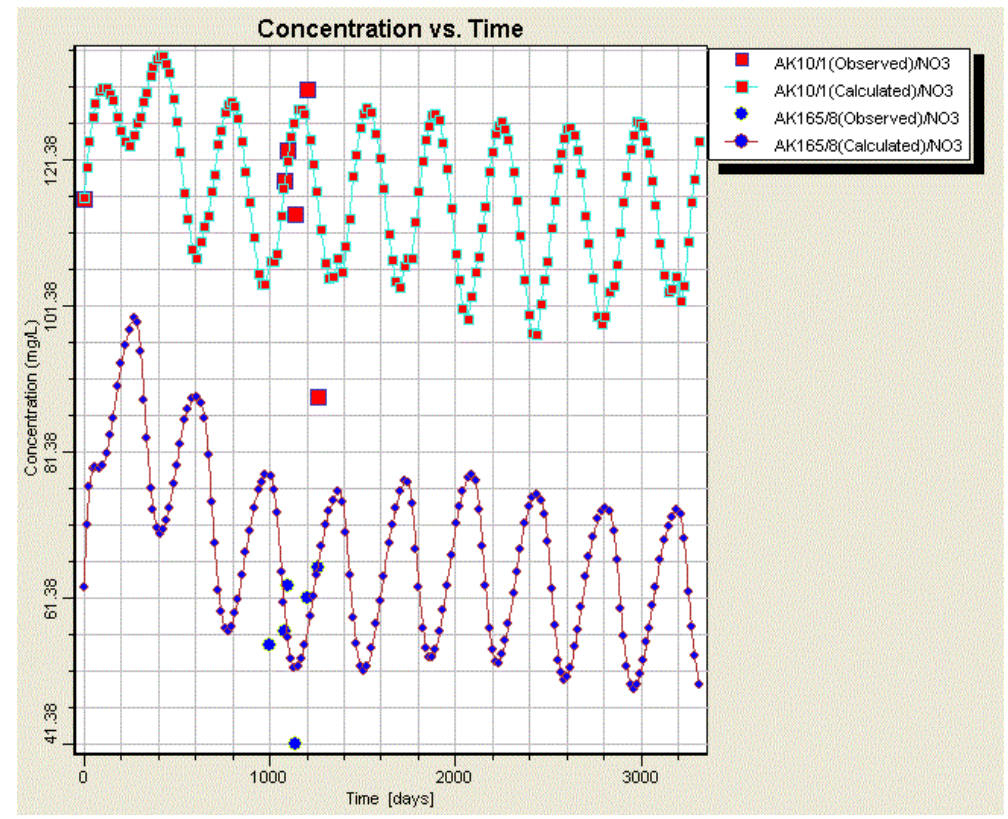

Figure 8. Measured and Simulated values in the Eastern part of the aquifer system. Nitrate concentrations are steadily above $40 \mathrm{mg} \mathrm{I}^{-1}$

According to Table 1 the mean nitrate concentration at forty three (43) sampling points on the Corinth's aquifer range from 1.3 to $132.6 \mathrm{mg} \mathrm{l}^{-1}$ while the average nitrate concentration in the groundwater of the study area was $53.7 \mathrm{mg} \mathrm{l}^{-1}$. Higher concentrations were measured during wet seasons and lower concentrations during dry seasons. To this pattern some exceptions were observed. Higher nitrate content in the summer for some wells can be attributed to the downward 
movement of shallow waters which are high in nitrate to the producing zones of wells during heavy pumping. Higher temperatures in the summer also favour nitrification of ammonia nitrogen retained in the soil from septic tank effluent.

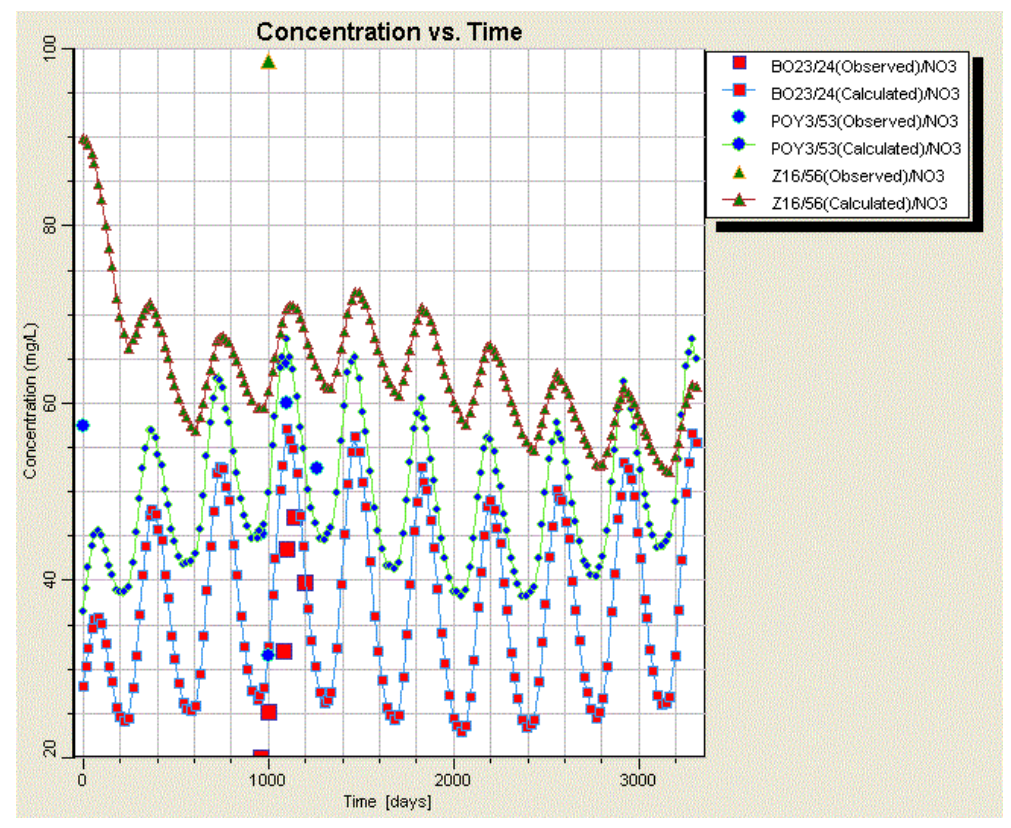

Figure 9. Measured and Simulated values in the Western part of the aquifer system.Nitrate concentrations are lower comparing to those of the eastern part of the aquifer system

The simulation results of the nitrate transport in groundwater Fig. 8 and Fig. 9 compare satisfactorily with the measured nitrate concentrations. The results show that the simulated concentrations increase during the humid seasons and decrease during the dry seasons in most of the wells. This temporal evolution is also seen in the measured nitrate trends. The nitrate concentrations are closely predicted by the model. The mean relative difference between measured and simulated concentrations ranges from 3.68 to $12.13 \%$.

In the case of the Corinth's aquifer Fig. 10 where nitrate ions behave as non-reactive chemical components, the axis of their maximum accumulation follows the main discharge axis of the aquifer. Zones of increased recharge of the aquifer coincide with zones of diluted nitrate ion concentration. According to field observations and nitrate transport modelling there was some spatial structure to the pattern of nitrate concentrations. The highest nitrate concentrations occupied the Eastern part of the aquifer system (Fig. 10) where lower rates of recharge are assumed according to the flow model.

Potential sources of these locally elevated nitrate concentrations point mainly septic tank discharges. Elevated rates of recharge at the western part of the aquifer system (Fig. 11) favours nitrate flushing, thus limiting the range of nitrate concentrations in the area. 


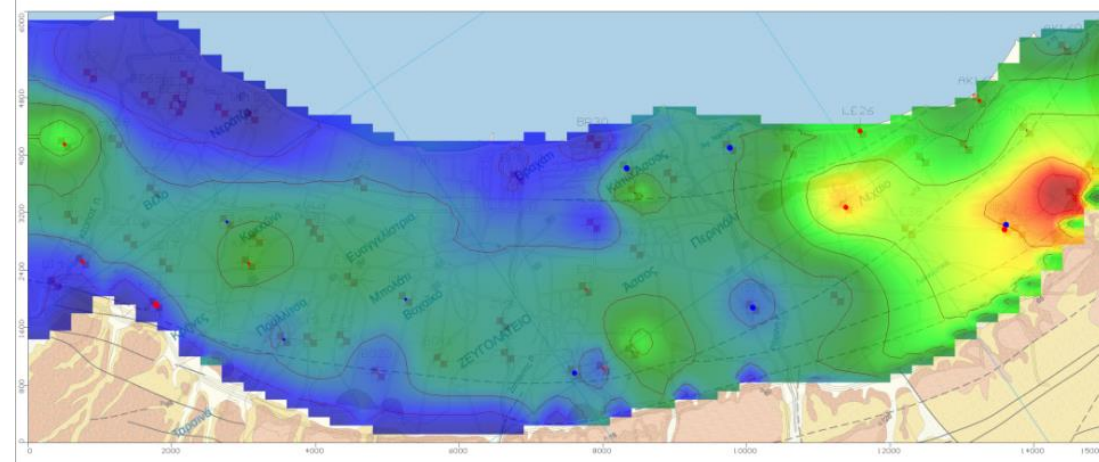

Figure 10. Modeled nitrate concentrations $\left(\mathrm{mg} \mathrm{l}^{-1}\right)$. Max concentrations are located in the Eastern part of the aquifer system

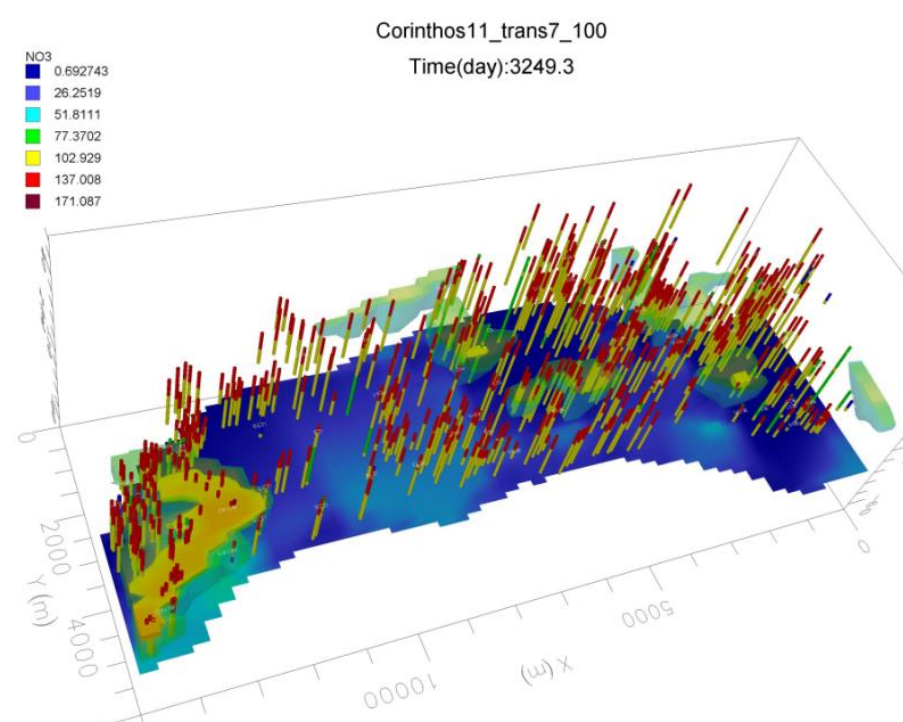

Figure 11. Modeled nitrate concentrations $\left(\mathrm{mg} \mathrm{l}^{-1}\right)$ for Winter 2006 show Low Concentration throughout the aquifer system

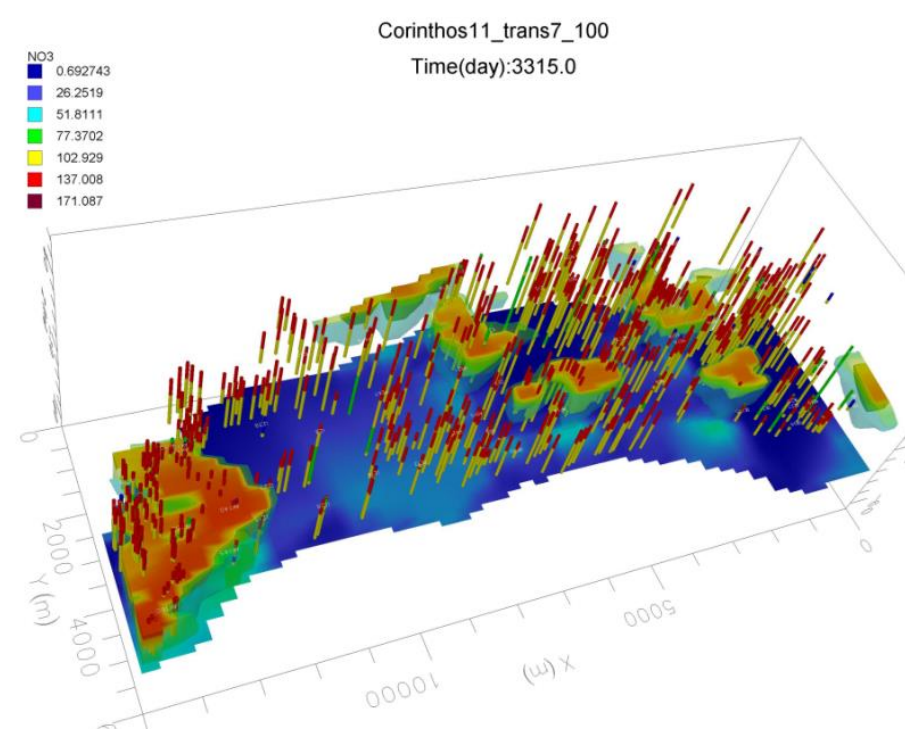

Figure 12. Modeled nitrate concentrations $\left(\mathrm{mg} \mathrm{l}^{-1}\right)$ for Early Spring 2007 show increased concentrations of nitrates starting to appear in the aquifer system 


\section{CONCLUSIONS}

Seasonal variations were observed in nitrate concentrations of water from wells. The patterns observed in Fig. 8 and Fig. 9 show a wavy distribution of $\mathrm{NO}_{3}^{-}$in the saturated zone. This distribution appears to reflect a combination of periodic pulses of water from rainfall and irrigation and variations in $\mathrm{NO}_{3}^{-}$availability due to crop uptake and mineralization.

Variations in nitrate concentration can generally be attributed to:

a. recharge conditions of the groundwater,

b. the changes in the concentration of the pollution sources,

c. changes of meteorological conditions (precipitation, evaporation),

d. groundwater level fluctuation,

e. changes in the amount of the groundwater abstracted from wells, and

f. agricultural activities.

The results of simulation compared to observed data, available over a period of one year, indicate that the approach coupling a spatially and temporally groundwater flow model with a simple transport model is acceptable. This particular methodology proved that a good model fit to the observed heads and the observed solute transport can be achieved.

Based on this transport model one can further explore different management practices assessing the impact of future nitrogen diffused pollution scenarios on the groundwater resources of Vocha plain.

\section{REFERENCES}

Almasri M.N. and Kaluarachchi J.J. (2005), Multi-criteria decision analysis for the optimal management of nitrate contamination of aquifers, Journal of Environmental Management, 74(4), 365-381.

Babiker I.S., Mohamed M.A.A., Terao H., Kato K. and Ohta K. (2004), Assessment of groundwater contamination by nitrate leaching from intensive vegetable cultivation using geographical information system, Environment International, 29(8), 1009-1017.

Bouwer H. (2000), Integrated water management: Emerging issues and challenges, Agricultural Water Management, 45(3), 217-228.

Burroughs W.J. (2003), Weather cycles: Real Or Imaginary, Cambridge University Press.

Currie R.G. (1974), Solar Cycle Signal in Surface Air Temperature, J. Geophys. Res., 79(36), 5657-5660.

Currie R.G. (1981), Evidence for 18.6 Year $M_{N}$ Signal in Temperature and Drought Conditions in North America Since AD 1800, J. Geophys. Res., 86(C11), 11055-11064.

Currie R.G. (1984), On bistable phasing of 18.6 year nodal induced flood in India, Geophys. Res. Lett., 11(1), 50-53.

Currie R.G. (1987), On bistable phasing of 18-6-year induced drought and flood in the Nile records since AD 650, International Journal of Climatology, 7(4), 373-389.

Currie R.G. and O'Brien D.P. (1988), Periodic 18.6-year and cyclic 10 to 11 year signals in northeastern United States precipitation data, International Journal of Climatology, 8(3), 255-281.

Currie R.G. and O'Brien D.P. (1990), Deterministic signals in precipitation records from the American corn belt, International Journal of Climatology, 10(2), 179-189.

Daskalaki P., Voudouris K. and Diamantopoulou P. (1998), Hydrochemical study of North Peloponnesus quaternary and pliopleistocene aquifers. Proc. Int. Conf. Protection and Restoration of the Environment IV, Sani, Greece, Vol 1: 108-116.

Freeze R.A. and Cherry J.A. (1979), Groundwater, Prentice Hall, Inc.

Hallberg G.R. (1989), Nitrate in groundwater in the United States. Nitrogen Management and Groundwater Protection. R.F Follet (ed), New York City, Elsevier Science Publishers B.V., Chapter 3, 35-74.

Koltermann C.E. and Gorelick S.M. (1996), Heterogeneity in sedimentary deposits: A review of structureimitating, process-imitating, and descriptive approaches, Water Resources Research, 32(9), 26172658. 
Koumantakis J., Panagopoulos A., Stavropoulos X. and Voudouris K. (1999), Application of aquifer artificial recharge in the coastal alluvial basin of the northern part of Korinthos prefecture, Peloponnese. Proceedings 5th Conference on Hydrogeology, Nicosia, Cyprus, 65-80.

Labitzke K., Loon H.V. and Shine K. (1990), Associations between the 11-Year Solar Cycle, the QuasiBiennial Oscillation and the Atmosphere: A Summary of Recent Work and Discussion Philosophical Transactions of the Royal Society of London, Series A, Mathematical and Physical Sciences, 330(1615), 577-589.

McDonald M.G. and Harbaugh A.W. (1988), A modular three dimensional Finite Difference Groundwater Flow Model. Techniques of Water Resources Investigations of the U.S. Geological Survey, Book 6, U.S. Government Printing Office, Washington, D.C.

Panno S.V., Krapac I.G. and Weibel C.P. (1996), Groundwater contamination in karst terrain of Southwestern Illinois, Illinois State Geological Survey Env. Geol. Series, 151, 1-43.

Psarropoulou E. and Karatzas G.P. (2001), Field Studies of Nitrate Mass Transfer in the Coastal Aquifer of Corinth, Greece. 7th International Conference on Environmental Science and Technology, Ermoupolis, Syros, Greece, Vol. B, 732-738.

Psarropoulou E.T. and Karatzas G.P. (2011), Transient groundwater modelling with spatio-temporally variable fluxes in a complex aquifer system: new approach in defining boundary conditions for a transient flow model, Civil Engineering and Environmental Systems, 29(1),1-21.

Ramachandra Rao A. and Hamed K. (2003), Multi-taper method of analysis of periodicities in hydrologic data, Journal of Hydrology, 279(1-4), 125-143.

Shamrukh M., Corapcioglu M.Y. and Hassona F.A. (2001), Modeling the Effect of Chemical Fertilizers on Ground Water Quality in the Nile Valley Aquifer, Egypt, Ground Water, 39(1), 59-67.

Voudouris K., Panagopoulos A. and Koumantakis J. (2000), Multivariate Statistical Analysis in the Assessment of Hydrochemistry of the Northern Korinthia Prefecture Alluvial Aquifer System (Peloponnese, Greece), Natural Resources Research, 9(2), 135-146.

Waterloo Hydrogeologic, Inc. (2006), Visual MODFLOW v.4.2, User's Manual, Waterloo, Ontario, Canada.

Zheng C. and Wang P.P. (1999), MT3DMS: A Modular Three-Dimensional Multispecies Transport Model for Simulation of Advection, Dispersion and Chemical Reactions of Contaminants in Groundwater Systems, Documentation and User's Guide, Contract Report SERDP-99-1, U.S. Army Engineer Research and Development Center. 